\title{
Shedding Light on Peri-Urban Ecosystem Services Using Automated Content Analysis
}

\author{
Gabriella Vindigni ${ }^{1, *}$, Alexandros Mosca ${ }^{2}$, Tommaso Bartoloni ${ }^{3}$ and Daniela Spina ${ }^{1}$ (D) \\ 1 Department of Agriculture, Food and Environment (Di3A), University of Catania, Via S. Sofia 98-100, \\ 95123 Catania, Italy; daniela.spina@unict.it \\ 2 Department of Physics and Astronomy, University of Catania, Via S. Sofia, 64, 95123 Catania, Italy; \\ alexandros.mosca@phd.unict.it \\ 3 Department of Project Cultures, Iuav University of Venice, Santa Croce 191, 30135 Venezia, Italy; \\ tbartoloni@iuav.it \\ * Correspondence: author: vindigni@unict.it
}

Citation: Vindigni, G.; Mosca, A.; Bartoloni, T.; Spina, D. Shedding Light on Peri-Urban Ecosystem Services Using Automated Content Analysis. Sustainability 2021, 13, 9182. https://doi.org/10.3390/su13169182

Academic Editors: Pasquale De Toro, Silvia Iodice and Francesca Nocca

Received: 15 June 2021

Accepted: 11 August 2021

Published: 16 August 2021

Publisher's Note: MDPI stays neutral with regard to jurisdictional claims in published maps and institutional affiliations.

Copyright: (c) 2021 by the authors. Licensee MDPI, Basel, Switzerland. This article is an open access article distributed under the terms and conditions of the Creative Commons Attribution (CC BY) license (https:// creativecommons.org/licenses/by/ $4.0 /)$.

\begin{abstract}
The objective of this paper is to provide an overall perspective on peri-urban ecosystem services in European Countries. The phenomenon of urbanization affecting our era has seen the shift of the city from compact and well-defined structures to agglomerations with a seamless expansion. This has led to several environmental consequences that have affected the urbanized areas and the surroundings. The peri-urban areas may be the main urban design and planning challenge of the 21st century. These hybrid landscapes, characterized by high fragmentation, can be turned into opportunities to improve the sustainability and quality of urban areas, generating multiple economic, social and environmental benefits. Areas beyond the immediate urban core can be considered a zone of influence, which represent a critical resource in terms of provisioning, regulating, supporting services and cultural ecosystem services. Our study has been developed in the framework of the project "Fertile Lands, Fragile Lands" funded by the University of Catania. A multi-phased method has been applied, showing strong, heterogeneous ties between landscape and ecosystem services. While the importance of literature studies on this topic is well recognized, the same attention has not been placed on the tools and methods of conducting systematic and incremental literature reviews. Using Leximancer software, we propose a text mining approach to extract relevant themes and concepts as well as related topics of interest from identified literature on peri-urban ecosystems. We first introduce the overall methodology and then discuss each phase in detail. The outputs can be used as starting point for broad exploratory reviews and allow further exploration in this issue. The results show how the peri-urban space can be seen as a mosaic in which the settlement, the agricultural and the environmental systems interact and coexist, placing at the centre the relationship of reciprocity between the built environment and the open territory.
\end{abstract}

Keywords: peri-urban; ecosystem service; landscape; text mining; automated content analysis

\section{Introduction}

Cities are increasingly in a process of transformation from well-defined agglomerations towards disordered and shapeless structures [1]. This urbanization process leads to environmental consequences in the cities and in their surroundings. In our research, we focused on the peri-urban landscape, the space around urban areas which merges into the rural landscape. Since they have high potential, these areas may be considered as one of the planning challenges of the 21st century.

Traditionally, peri-urban space has been seen as a separation between urbanized areas and indefinite places, between city and countryside. Several studies have attempted to overcome these interpretations, capturing their potential to implement processes which contribute to urban sustainability transitions, offering an opportunity to invest in environmental safety, the improvement of ecological performance and the urban environment, also 
in terms of the quality of public space and in the economic dimension. Urban sustainable transition researchers have raised the issue on how to deal with the ecosystem services in consolidated city and in its suburbs, "where the city is no longer a city and the countryside is not yet countryside" [2].

Peri-urban landscapes can be seen as a spatial and figurative broken network, characterised by fragmentation, lack of urban and ecologic continuity, hybrid (not-rural, noturban) environments, thus lacking identity.

Urban hybridization involves the contamination of territories (urban-rural) with their own identity [3]. It implies the coexistence and intermingling functions in a specific area. According to Ellin [4] and Zanni [5], the development of these areas is an integral part of contemporary societal growth and is linked to the rapid transformation of patterns in the urban fabric.

Hybrid spaces are critical resources for the economy of a city, as they constitute the drivers of spatial, social and public changes [6].

Jencks [7] argues that the postmodernist science of complexity has influenced the development of multifunctional, hybrid urban spaces. Zanni [5] highlights that urban hybridization is determined by the multi-layered and multi-scaled urban fabric.

However, areas beyond the immediate urban core can be considered as zones of influence which represent critical resources both in terms of provisioning, regulating and supporting services and habitat ecosystem services. Peri-urban landscapes include different types of ecosystems that are able to deliver a diverse set of services. They provide to the urban core water and climate-related regulating services, such as air filtration, cooling and ventilation [8,9], which are necessary elements to mitigate the effects of climate change. These areas beyond urban areas are part of larger ecological networks for biodiversity and green infrastructure [10-12]. The provision of food represents the major ecosystem service [13], as agriculture represents the prevalent land use. From a cultural viewpoint, these landscapes are seen as important areas for citizens' outdoor recreation [14,15]. These areas, mainly woodlands, fringe forests, country and agricultural parks and green open spaces that offer the user multifunctional recreation possibilities and different kind of nature [16].

The ecosystem services definition has been developed in Millennium Ecosystem Assessment [17], but there are still uncertainties related to this concept, as well as conceptual fuzziness and social controversies [18-20]. Therefore, it has been identified as a "boundary object" [21,22]: strong enough to link different points of view and values within a scientific community while remaining a nuanced concept capable of maintaining participants' identities.

Research on urban ecosystem services has been proliferating and new developments in this field of research are evident, but little attention has been devoted to the periurban space. Internationally debated, the concept of Landscape Urbanism [23] is gaining ground with the idea of interpreting the city as a "living organism", applying the same principles of the biological world towards an ideal model a of "metropolis landscape". It is based on the widely recognised principles of sustainability, sharing and resilience. At present, the condition of our cities is characterized by a high demand for resources (energy, water, raw materials, food, soils), which are the main inputs deriving from the territories and by the urban outputs that are poured into them (waste, emissions, consumption, various externalities). It is critical to balance this exchange of inputs and outputs between territories in urban fringe and cities to produce goods and services (input) and to absorb anthropogenic actions (output) with a focus on sustainable development.

The purpose of this article is to provide an overview of peri-urban ecosystem services in European countries, in order to contribute to the debate on how to promote resilience and sustainability as their main assets. We first discuss the peri-urban landscape that hosts a mixture of ecosystem functions and supports new urban configurations. Our research considers the peri-urban landscape as a privileged key to interpreting hybrid spaces, still 
poorly understood by the planning culture, in which regeneration drives the enhancement of rural areas.

To synthesize the latest advances in the research, a systematic review of recent literature on peri-urban ecosystem services was conducted to identify current research trends. A semi-automated content analysis using a text-mining tool called Leximancer has been adopted on studies published in Scopus-indexed journals. While text analysis is not a new field in the academic community, automated content analysis is gaining ground because of its advantages in information processing for literature synthesis purposes. It provides instrumental assistance to analyse a large amount of textual data in the context of increasingly digitized information, providing a framework to critically investigate the existing literature or highlight issues that are relevant in a field of study.

\section{Urban Growth and the Implications on Peri-Urban Landscapes}

Continued and rapid urbanization influences people's quality of life since it limits the availability of green space and vegetation. The more that cities expand and become more dense, the more that ecosystem services provided by open public spaces are important for local residents in terms of public health, well-being, provisioning services and resilience $[24,25]$. This expanded model has been defined by the international literature as sprawl in Italy, a "widespread city" [26], a form of "frayed urbanism" [21] and a dispersed territory that produces a rarefied metropolis in dissolution. Sprawl, which manifests itself in peripheral areas in the form of urban dispersion resulting from the rapid and disordered growth of cities, has also made the definition of periphery complex. The growth of the urban system has led to a peri-urban landscape characterised by patches of buildings with small tracts of natural or semi-natural habitat (e.g., forest patches, parks). Peri-urban zones grow outwards into the rural hinterlands and become increasingly multifunctional, changing the way in which land is used and consumed $[27,28]$. Peri-urban landscape reading shows a high presence of areas characterised by fragmentation, lack of urban and ecologic continuity and dispersion of a sense of place [29]. The boundaries that delimit the compact neighbourhoods are generally very poorly defined and usually coincide with the morphological characteristics of a territory [30]. In other cases, the borders coincide with infrastructure such as railways, highways, artificial dams and other boundaries. Finally, internal boundaries are often determined by social characteristics of historical or contemporary settlements. Peri-urban areas will, over time, become embedded in cities and therefore their landscapes should be seen as a functional extension of the city rather than peripheral, spatially fringe land. Such zones are often defined as residual or marginal areas and - not being seen as integral parts of our cities - their social, cultural and ecological potential is undervalued [31]. In ecological terms, such spaces need to be seen as networks and green corridors, the outcome of organising the remaining free areas. [32]. As such, they constitute a significant reserve for biodiversity. Today, peri-urban areas consist of a frayed and unstable settlements, with patches of marginal green parcels bordered by infrastructure and constructions that are completely external to rural activities, with a significant environmental impact [33]. Urban growth in Europe, especially in the south and in most Mediterranean areas, as in Italy, is characterized by "horizontal expansion", which has led to a reduction of available land. According to the most recent data [34], the sealed soil increases by 57 million square meters per year, i.e., two square meters per second. This phenomenon has created unprecedented growth of new hybrid landscapes [3], characterised by the persistence of vast agricultural and natural areas within the metropolitan perimeters. A discontinuous, anonymous and endless city [35] continues to sprawl far beyond the boundaries of the large suburbs built since the second half of the twentieth century. Peri-urban areas can be seen as a patchwork of landscapes, encompassing not only the areas surrounding the city, but also the historic centre, the consolidated districts of the public city, the large infrastructure, agricultural areas and fringe greenhouses. This phenomenon has been generated by the dynamics of divestment, abandonment, reuse and contamination, constantly mixing materials, relationships and different social actors 
in chaotic directions [36]. The "horizontal city" [27] and the urban dispersion that it generates, in particular in the South of Europe, represents an emergency which can only be addressed by experimenting with innovative, interpretative and operational approaches. Most buildings, infrastructures and "recyclable" open spaces are concentrated within the "horizontal" urban settlements of recent construction.

Therefore, contemporary metropolitan reality has been defined in several ways: "megistopolis" (Gottmann), "in (d)efinite city" (Krstic), "soft city" (Raban), "global city" (Sassen) and "exopolis" (Sorking) [37-41]. In an attempt to synthesize the characteristics of some metropolises or of sprawl, "no town" and "slurb" have been used to refer to the physical diffusion process, and "patchwork" (Neutelings), "urban island" (Ungers) and "hyperville" (Corboz) [42-44] have been used to replace terms such as suburb or banlieu.

Urban voids and abandoned spaces can be transformed into opportunities through their reuse, thereby improving urban quality with multiple economic, environmental and social advantages. Emerging opportunities for urban resilience planning and design can be achieved through the reduction of risks linked to climate change and floods, the improvement of water quality and other ecological and ecosystem benefits, together with the advantages deriving from urban agriculture, such as production and access to food. Improving the future quality of life in cities is strictly linked to rethinking peri-urban areas in urban planning.

In these belt contexts of European cities, attention is focused on land stocks [45], which can be understood as those residual areas or those voids capable of constituting a "deposit" of territory or a "reserve", in the sense that Clément attributes to them, that is, unexploited places that constitute a refuge for diversity [46], or as waste landscapes, theorized by Berger, in the sense of spaces left behind by development, left without destination, residues of a rapid process of urban transformation [47]. From a theoretical point of view, various contributions such as the Manifesto of the Third Landscape [48] affirms the biological potential of these urban spaces that are not built and abandoned or left uncultivated. The storage of these areas has enormous potential in providing ecosystem services of immediate availability, dictated by their proximity to cities. They play an important role in the metabolic logic by providing material and immaterial resources, capacity to absorb and contain urban externalities and limits to further urban expansions and resources to face climate changes challenges. These areas, if appropriately reconnected within integrated visions and strategies, are ideal for the urban transition towards greater criteria of sustainability and resilience. Gilles Clément [48], in his essay, refers to the ecological potential expressed by friches, residual and uncultivated territories (délaissé) abandoned by human activities or never exploited but which are fundamental for the conservation of biological diversity. This perspective goes beyond the contents of the European Landscape Convention, a highly innovative document when compared to the landscape and environmental policies of recent decades. It focuses on residual open spaces devoid of identity and does not limit itself to dignifying to those "ordinary" landscapes or conceiving such safeguarding policies as conservation and maintenance of the significant or characteristic aspects of a landscape.

"Starting from what remains" [22] is the basis on which to build a project idea of the landscape and the periphery in order to use its existing resources with a single strategy and vision, taking into account climate change, environmental and social emergencies and placing the active involvement of local communities and citizens at the centre of urban regeneration projects.

Landscape is the emergent theme and the predominant strategy to face the environmental and social emergencies of our cities. New challenges have emerged for the protection and safeguarding of such an important element as the landscape in terms of the heritage that interacts with community and individual life, climate change, the depletion of natural resources and the conflict between globalization and local development. It often surpasses national boundaries and creates the need for global response in the EU's urban strategy. It can be interpreted as a result of the general process of urban reorganization, that 
underlines the limits of a dualistic approach to territorial "metropolization", de-coupling form from functions. Some cities in Europe have developed urban transformation strategies that place the landscape as the fulcrum of vital processes of urban transformation to generate a new quality of life for the inhabitants. This role has been recognized by the European Landscape Convention [49], according to which landscape is an essential component in cultural, ecological, environmental and social fields as well as for individual and social well-being and quality of life. Similarly, the Convention recognises that landscape is an indispensable asset, favourable to economic activities and economic growth.

Fragmented open spaces are therefore places to experiment with participatory practices, with the active involvement of the communities of inhabitants in the process of re-appropriation of the space. Valorising the peri-urban landscape is a resource for society and an economic opportunity. The residuals within the urban and peri-urban spaces can play a fundamental role to improve the quality of the city life. Promoting new functions and public services in these areas, protecting the remaining signs of the cultural and natural heritage, "rediscovering" these places and taking them out of the margins.

\section{Materials and Methods}

For this systematic review of peri-urban ecosystem services in European literature, an initial overall assessment of the content was performed by descriptive analysis of the main characteristics of the studies. A text mining tool was then adopted to generate a list of the most frequently appearing word-level concepts that appear in our selected documents and a concept map which shows interconnected concepts.

\subsection{Descriptive Analysis}

To investigate ecosystem services in European peri-urban areas, we analysed the scientific peer review of journal articles from Scopus database published over a 10-year period. The selection criteria have been identified in a reproducible and transparent way. The following search terms were used to identify studies suitable for inclusion: "ecosystems AND services AND peri-urban OR peri-urban OR fringe". Due to the interdisciplinary and broad character of the subject of ecosystem services, we selected only journals of social science disciplines. The search returned 482 unique records that were subsequently screened. We removed studies published before 2012. Of the remaining 136 records, we included only papers which were related to European countries. Other criteria of exclusion were as follows: non-academic articles such as editorials, commentaries, conference papers, book chapters or research summaries and papers not in English and with no full-text access. Of 67 studies retrieved, 12 studies were excluded because the outcomes were outside for our review questions (Table S1 in Supplementary Materials).

The papers were also analysed to find trends in which journals they had been published over the years (Table 1). The studies about ecosystem services in European peri-urban areas (subject area social science) from 2012 to 2021 total 55 and have been published in 15 journals.

Figure 1 shows the geographical distribution of case studies about ecosystems in European countries (from Scandinavia, including eastern countries, to Mediterranean countries). The majority of the research was conducted in Italy (14 studies), followed by Spain (13 studies), UK and Germany (6 studies) and France, Belgium and Switzerland (4 studies).

The analysis has taken into consideration the MEA category to which the services belong and the research perspective [50].

Our pool of case studies mentioned all categories of ecosystem services. The categories of ecosystem services were elaborated with the $R$ software [51] and plotted with the $R$ package ggplot2 [52]. In some papers, more than one ecosystem service is investigated at the same time. Cultural services were mentioned most often (33 case studies), following by regulating (21 case studies) and provisioning (16 case studies). Supporting services were least studied (5 case studies), as shown in Figure 2. 
Table 1. Total publication per journal and per year. (Author's elaboration from Scopus database).

\begin{tabular}{|c|c|c|c|c|c|c|c|c|c|c|}
\hline Journal & & & & & & & & & & \\
\hline Agroecology and Sustainable Food & & & & & & 1 & & & & \\
\hline Systems & & & & & & & & & & \\
\hline Agroforestry for Sustainable Landscape & & & & & & & & 1 & & \\
\hline Management & & & & & & & & 1 & & \\
\hline Applied Geography & & & 1 & & & & & 1 & & \\
\hline Ecosystem Services & & & & & 1 & 1 & 1 & 1 & 1 & \\
\hline Environmental Science and Policy & & & & & & & 1 & & 2 & \\
\hline European Spatial Research and Policy & & 1 & & & & & & & & \\
\hline Global Environmental Change & & & & & & 1 & & & & \\
\hline Humanities and Social Sciences & & & & & & 1 & & 1 & & \\
\hline Communications & & & & & & 1 & & 1 & & \\
\hline $\begin{array}{l}\text { Integrated Environmental Assessment } \\
\text { and Management }\end{array}$ & & 1 & & & & & & & & \\
\hline Land Use Policy & 1 & 1 & & & 3 & 1 & 1 & 1 & 2 & 1 \\
\hline Landscape Ecology & & 1 & & & & 1 & & & & \\
\hline Landscape Research & & & & & 1 & & & & & \\
\hline Moravian Geographical Reports & & & & & & 1 & & & & \\
\hline Nature Policies and Landscape Policies & & & & & 1 & & & & & \\
\hline Planning Practice and Research & & & 1 & & & & & & & \\
\hline Progress in Planning & & 1 & 1 & & & & & & & \\
\hline Sustainability & & & & & 1 & 1 & 3 & 4 & 6 & 1 \\
\hline $\begin{array}{l}\text { The International Journal of Sustainable } \\
\text { Development and World Ecology }\end{array}$ & & & & & & & & & 1 & \\
\hline Urban Ecosystem & & & & & & 2 & & & & \\
\hline Sub-total & 1 & 5 & 3 & 0 & 7 & 10 & 6 & 9 & 12 & 2 \\
\hline Year & 2012 & 2013 & 2014 & 2015 & 2016 & 2017 & 2018 & 2019 & 2020 & 2021 \\
\hline
\end{tabular}

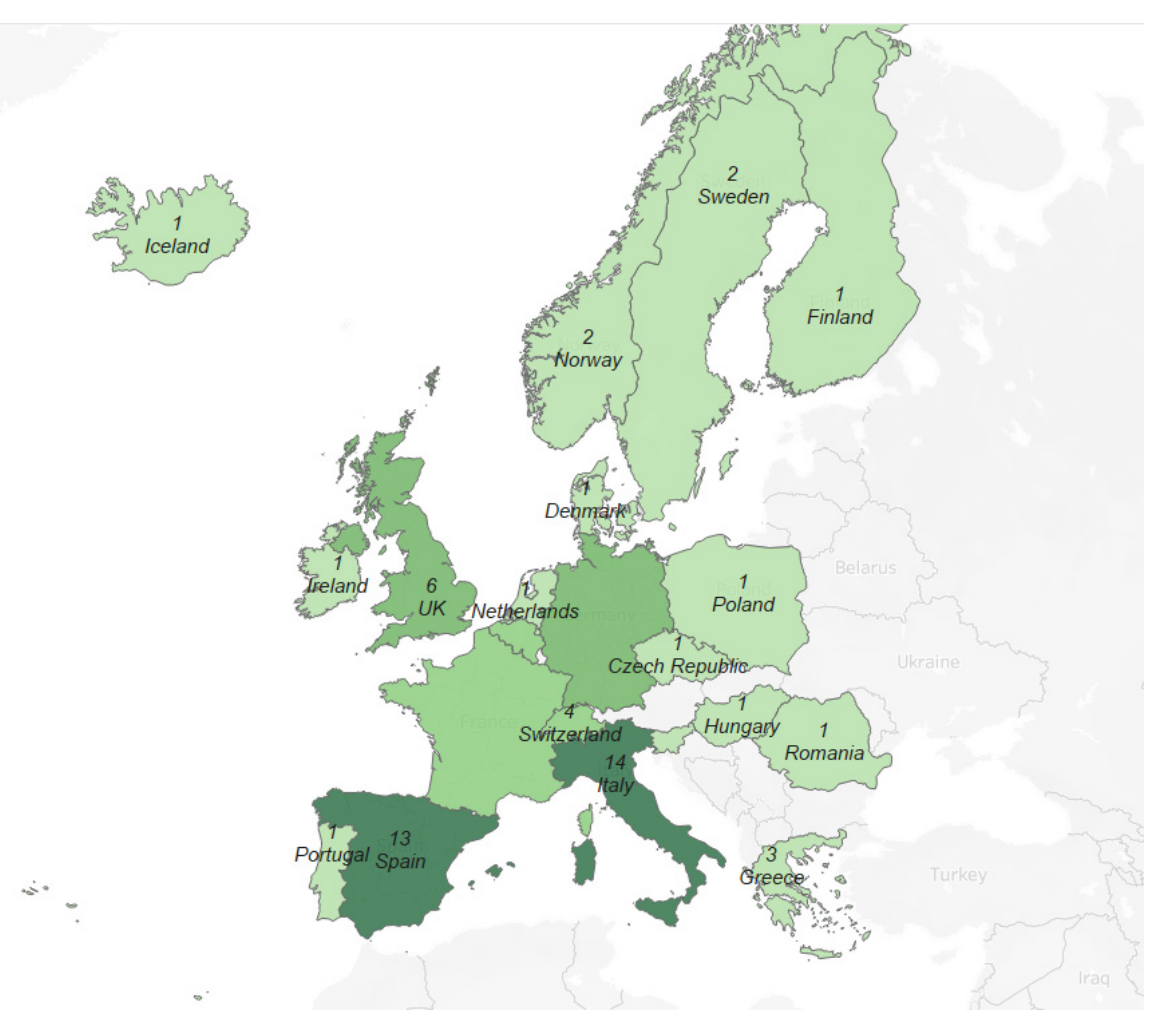

Figure 1. Countries investigated in the selected publication (author's elaboration on Scopus database). 


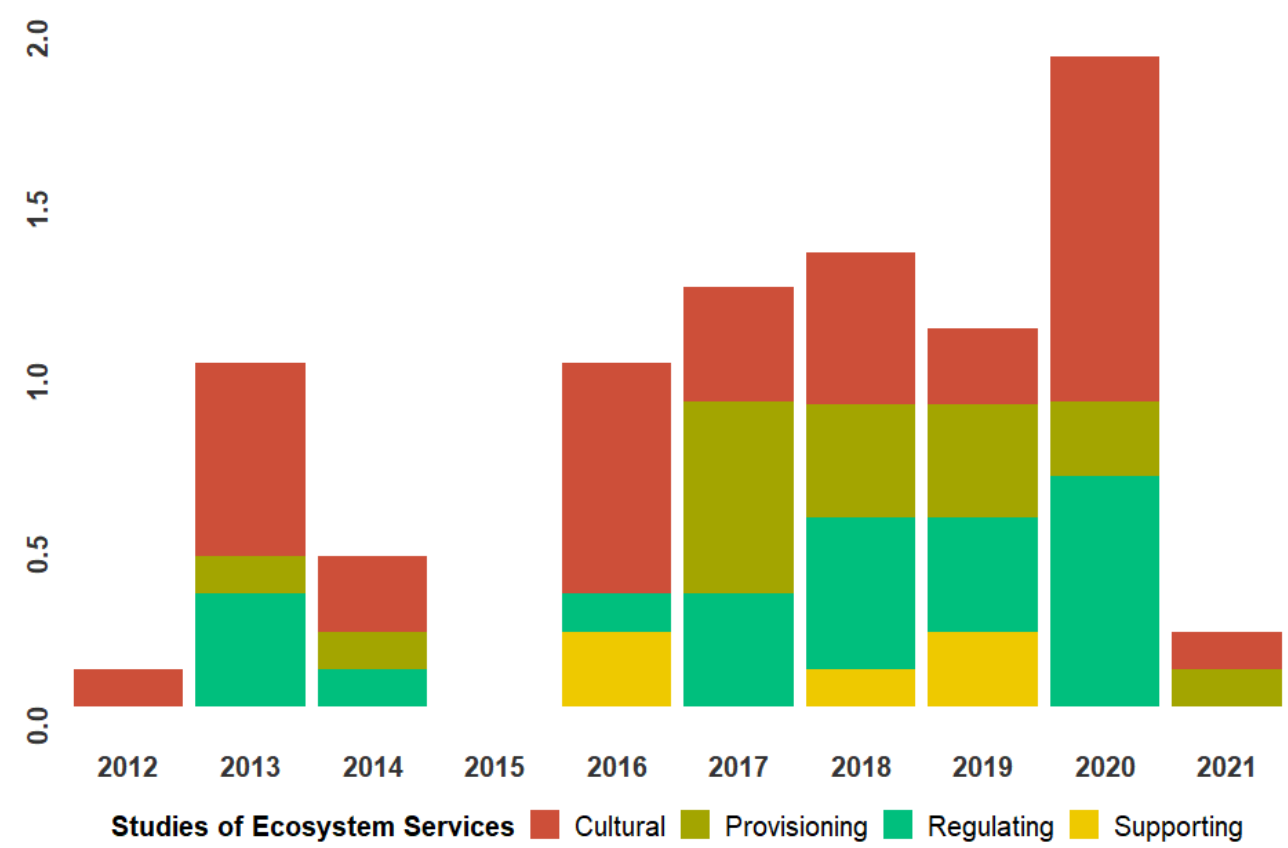

Figure 2. Distribution of category of the ecosystem services studies over time (author's elaboration).

In our research, we also analyse the main research perspectives of the selected dataset. For our elaboration, we have considered the data of the studies in terms of proportion (Figure 3).

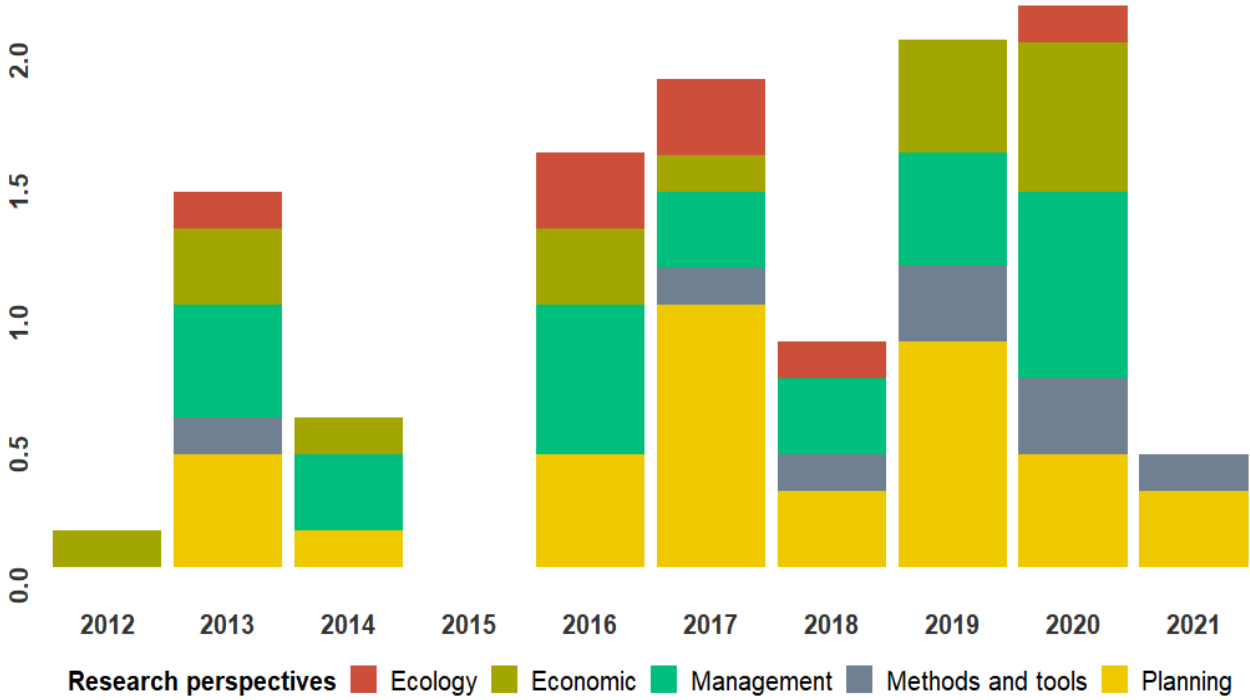

Figure 3. Distribution of the examined ecosystem services through the main research perspectives over time (author's elaboration).

The most services were mentioned in papers with a planning and management perspective, followed by a social perspective, while ecological and economic perspectives had a smaller share. Our results further show that methods and tools attracted less research attention. Only a small number of papers investigate peri-urban ecosystem service with this perspective (8 case studies).

\subsection{Automated Concept Analysis Using Leximancer}

Automated content analysis refers to a set of algorithms that use probabilistic models, known as "topic models" or "concept mapping" models [53], to highlight the main patterns in a body of literature. 
In this study we adopted Leximancer software, a text-mining tool that uses machine learning to identify and define concepts within our specific dataset of studies regarding ecosystem services in European peri-urban space. The software analyses the most frequent concepts and their relationship within the text and individuates the co-occurrence with other words and synonyms.

Leximancer processes data texts and extracts "concepts" and "themes". In the Leximancer manual, "concepts" are collections of words or terms that are associated in the text and share similar meanings or spaces within the text. "Themes" are concept groups which show close proximity. The hierarchy of "importance" indicates concepts which are highly connected $[46,54,55]$. The software weighs these terms according to how frequently they occur in sentences containing the concept [56]. During the learning process, words highly relevant to the seed are continuously updated and eventually form a thesaurus of terms for each concept. The advantage is that the software extracts a list which displays the weight of terms and their connections from the imported documents, helping in the synthesis process [57].

The automated concept analysis can be performed in three main steps: identification, definition and concept classification. The first step (concept identification) is dedicated to identifying "concepts" in the literature through the use of "concept seeds". Therefore, single words that occur frequently in the data set represent the most important concepts, which can be extracted from the literature through an unsupervised or a supervised method. The second step (concept definition) builds a thesaurus (i.e., a group of words that forms a concept) which is elaborated for each concept. The thesaurus has key role for the construction of the topic model or concept mapping algorithm.

The third and final step (text classification) analyses and chooses a classification resolution in order to produce an indexed version of the literature. In our research study, the Leximancer software was able to generate graphic summaries of results, specifically concept maps that illustrate the level of connections between key words in the text being analysed [58]. The visual lexical map allows a general overview of the data. Themes are summarised into circles and identified by the largest numbers of "dots" within the group; the size of the dot indicates the importance of the concept. The proximity of two concepts indicates how often they appear in similar conceptual contexts. So, when two concepts are placed at a distance from each other, it indicates that they are not used in the same context. Concepts that attract each other and are clustered together are grouped into themes, which are displayed as coloured circles. Hot colours (such as red and orange) depict the most important themes, and cool colours (blue, green) denote those less important in relation to our selection of papers. It is the colour of the themes that demonstrates their prominence, rather than the size of the circle, which is not relevant. An advantage is that the map is interactive and allows the research to further explore the concept and their connectivity, linking the software findings back to site in the original text [59]. Meaningless themes and concepts have been removed to attach value and relevance to those useful for the analysis. Therefore, choices at each stage of the process are reversible so it is possible to refine the analysis and the presentation graphics in order to tailor them to the task of the research.

In Figure 4 we illustrate the process of an automated content analysis divided into three stages: identification concept, definition concept and text classification. When the process is complete, the researcher gains access to the final output. 
Step 1: concept identification

Step 2: concept definition

Step 3: concept classification

Final output

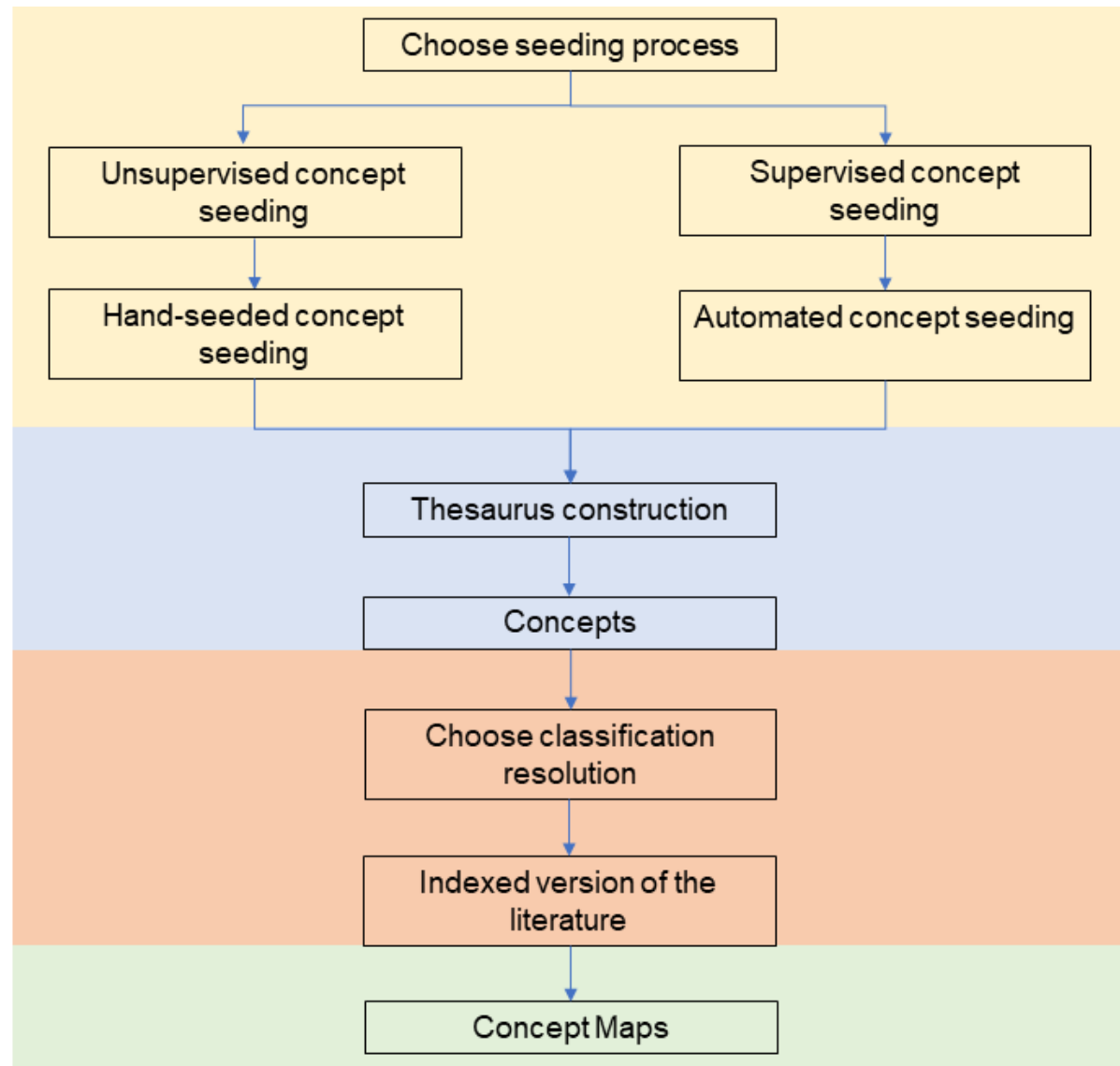

Figure 4. Workflow of the stages of automated content analysis (author's elaboration).

\section{Results}

The Leximancer analysis of all 55 papers included in our peri-urban ecosystem services literature review has produced four main themes, as shown in the histogram bar (Figure 5), which ranks their relative importance.

THEME

services

urban

landscape

species

\section{HITS}

6725

3985

3720

1920

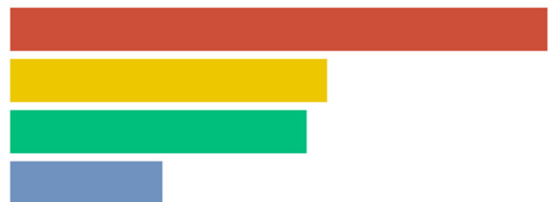

Figure 5. Themes identified by Leximancer.

After running the learning process and developing a list of concepts contained in the text, their relationships to each other are presented in a Concept Map (Figure 6). A zoomed out $(62 \%)$ perspective of theme and constituting concepts is derived from the analysis of the studies in the pooled dataset. Zooming in and zooming out can be used to reveal overlapping or dominant concepts and to invite further exploration of the data and to better understand connections. Figure 7 also shows how the presentation of findings can be visualized focusing on the concept "peri-urban". In addition, Table 2 reports the rate of the themes connected to the investigated literature and the automated concepts within each theme. 


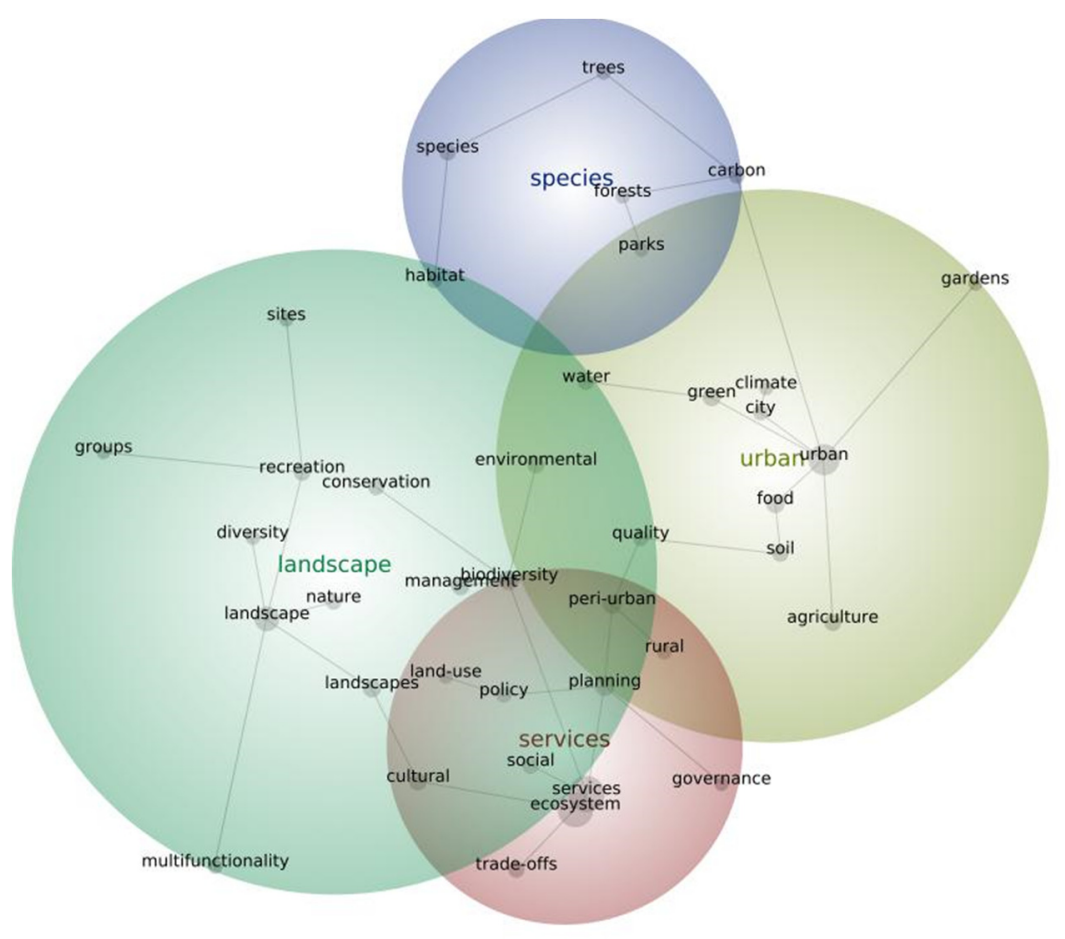

Figure 6. Leximancer concept map. Theme size $62 \%$.

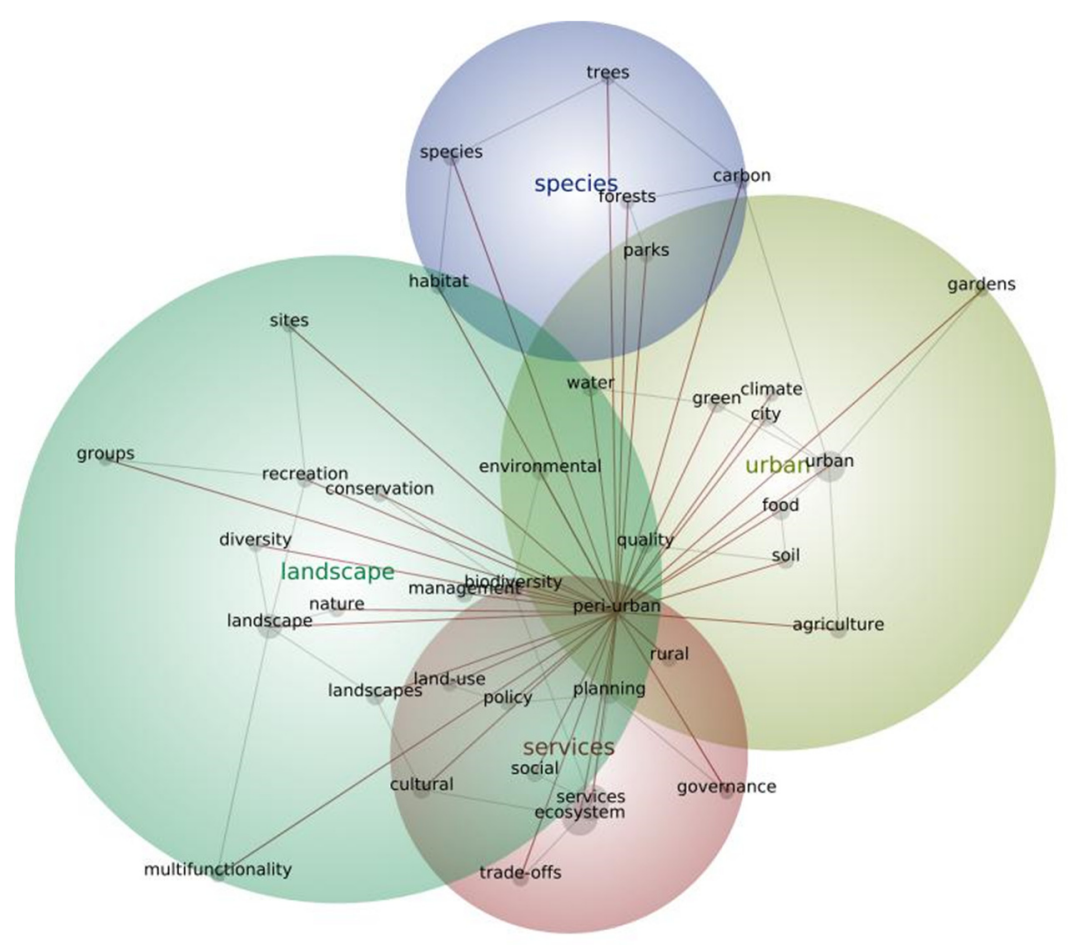

Figure 7. Presentation of findings related to the term "peri-urban".

The conceptual map indicates that the themes of "Ecosystem Service", "Landscape" and "Urban" are highly connected and the circles of each cluster are overlapping. The role of ecosystems services is central for the well-being of people living both in consolidated cities and on the urban-rural fringe. "Peri-urban" is the core of the intersection among clusters, highlighting that these areas are crucial resources for ecosystem services and involve a complex planning of social and ecological aspects as they become absorbed into the sphere of the urban economy. The environmental and economic crisis of urban areas 
has emphasized the opportunities that peri-urban spaces can offer for an urban resilience project. At the same time, these areas contribute to environmental safety, the improvement of ecological performance and the urban environment, to the quality of public space and to the economic dimension.

Table 2. Rate of connection themes with our peri-urban ecosystem service.

\begin{tabular}{ccc}
\hline Theme & Connection to the Ecosystem Services Literature (\%) & Automated Concepts within Theme \\
\hline Services & $100 \%$ & Cultural, ecosystem, management, social \\
\hline Urban & $59 \%$ & Agriculture, food, soil \\
\hline Landscape & $55 \%$ & Biodiversity, multifunctionality, recreation \\
\hline Species & $29 \%$ & Forests, trees, parks \\
\hline
\end{tabular}

Ecosystem services (darkest red circle) is the dominant theme. The concepts included are "Governance" and "Trade-off", indicating that in our studies, authors have investigated more into these topics. This theme is linked to the cluster of "Landscape" and "Urban" through the recurrence of the concepts of "social", "cultural", "policy", "land-use", "planning", "rural" and "peri-urban". Ecological and human system interaction have been considered in recent years due to pressing environmental challenges such as climate change, biodiversity loss and land degradation. The increasing urbanization implies the need to promote the quality of life of people and to better manage the transition towards sustainability [50].

Ecosystem services have a fundamental role in human well-being, both directly and indirectly, and therefore, they represent part of the overall economic value of the planet [60].

However, because they are not adequately quantified in economic terms, they are undervalued in policy decisions. According to Costanza [60], this neglect may ultimately compromise the sustainability of humans in the biosphere; in this sense, their economic value is infinite. The concept "Trade-off" in the ecosystem services literature indicates a situation when a resource management decision generates an increase in one service and a decrease in another service [41]. Therefore, trade-offs between ecosystem services can result in conflicts due to the intrinsic constraints of the biological, ecological and physical systems, as well as the divergent preferences expressed by different stakeholders [61]. In the ecosystem services framework, the definition of trade-offs is mainly derived from the Millennium Ecosystem Assessment [17] category and is defined as management choices that intentionally change the services provided by ecosystems. In addition, The Economics of Ecosystems and Biodiversity (TEEB) described the trade-offs of ecosystem services as the way one ecosystem service responds to the changes in another service [62]. There are also some refined definitions of trade-offs, indicating the interactions among ecosystem services that result in the increasing provision of one ecosystem service at the cost of other services [63]. Generally, trade-offs of ecosystem services occur when human interventions improve the output of an ecosystem service while negatively impacting the provision of other services $[64,65]$. For those concerned with trade-offs in ecosystem services, the main problem is that agricultural intensification related to the provisioning of ecosystem services usually reduces or damages other ecosystem services related to the ecosystem regulation and maintenance, as well as cultural services [66]. Little attention is paid in literature to ways in which different types of ecosystem service decisions are made, to what arguments are effective in turning policy into practice and, in general, to how ecosystem services are governed [67]. Spyra [13] acknowledges the limited research on the governance of ecosystem service trade-offs. In many cases, governance has so far been unable to address the heterogeneity of the actors involved. Innovative governance must be implemented by joint efforts of actors located at different levels (from region to municipality or district) and working under consensus-oriented leadership.

Urban (gold circle). Several authors of our set of studies highlighted the role of urban agriculture. Urban agriculture is not only recognized for the social and economic aspects 
of food production and the supply of food, fuels and fibers but also for its increasingly broad and multifunctional role that includes intangible, and therefore difficult to quantify, benefits such as maintaining fertility, soil, pollinator regulation, water quality and supply and greenhouse gas emissions [68]. Agriculture can provide all three major categories of ecosystem services, procurement, regulation and cultural services $[69,70]$. Researchers found that urban dwellers increasingly rely on urban agriculture, and food production is shifting from an anonymous production to become more familiar, as consumers are increasingly aware and want to know who their farmer is and where the food comes from [71]. Pinto-Correia et al. [72] have underlined that nowadays in Europe, more and more small farmers have exchanges with areas outside of rural areas, giving rise to new balances between food production and the landscape. Artmann [73] critically reflects on ecosystem disservices dealing with potential agricultural health risks through soil and crop pollution. However, he argues that not all sites investigated by the studies exceed the limits of contaminations and the level of risk strongly depends on their land use history and impact by anthropogenic activities.

Soil is another critical concept in ecosystem literature. It plays a role in water cycle regulation, which becomes increasingly important for climate change management, for example, to reduce the impact of precipitation events and in floods in residential areas [74]. Soil ecosystem services include carbon transformations, nutrient cycling, maintenance of the structure itself and the regulation of biological populations. The EU Soil Thematic Strategy [75] identified that the main threats to soil are erosion, reduction of organic matter, local and diffuse contamination due to toxic substances, sealing, decline in biodiversity and salinization. These changes affected the physical, chemical and biological characteristics of soil, which lead to a reduction in potential agricultural productivity and raise concerns about food security, mainly from the perspective of a growing world population [76]. Calzolari [77] claims that the management of soil sealing in urban areas does not always explicitly take into account the properties and functions of the different soils, hence the quality and functions of the associated ecosystem services.

In the context of the urban cluster, urban ecosystems are referred to both the built infrastructure and the ecological infrastructure, which include the concepts of "water" and "green" in urban and peri-urban areas, such as gardens, courtyards, parks, cemeteries, courtyards, urban vegetable gardens, green roofs, wetlands, streams, rivers, lakes and ponds [62]. The cluster also shows the concept "garden" as evidence that the origin of domestic gardens is strongly linked to the history of urbanization [78]. Residential development is often accompanied by private or collective gardens. However, the increase of garden area is not only a consequence of housing. Gardens themselves may be an object of investment and restructuring $[79,80]$. For example, gardens in the countryside or peri-urban areas are expanded by annexing an adjacent agricultural parcel to the garden.

Landscape (green circle) in the examined literature has different characteristics and has been described mostly as peri-agricultural landscape, according to the dimensions of the urban areas and the geomorphological and functional features of the surrounding areas. However, with its different connotations, landscape is described as peri-natural and peri-forest, and it can be seen as a critical zone between demographic pressure tied to the needs of human beings and the conservation of natural resources.

In the growing literature on cultural ecosystem services, landscape has received considerable attention [81-85]. Cultural ecosystem services are widely assumed to be the non-material and intangible benefits arising from multi-dimensional human-nature relationships, such as cultural heritage, place identity, spiritual enrichment, cognitive development and learning $[86,87]$. Intangibility, subjectivity and lack of standardized assessment are the main characteristics of cultural ecosystems services, and therefore, they are difficult to systematically quantify and map. Outdoor recreation can be classified as a cultural ecosystem service (CES), covering "all the non-material, and normally nonconsumptive, outputs of ecosystems that affect physical and mental states of people". Landscape also provides aesthetic and psychological benefits from green spaces; they 
usually help reduce stress and increase physical and mental well-being [88]. Komossa [89] identified large variations in outdoor recreation, including short-term recreation in nearby green space, one-day or overnight tourism [81], educational recreation [90,91], spiritual recreation [92] or nature tourism [93]. Parks, forests, lakes and rivers provide multiple possibilities for recreation, enhancing human health and well-being and vary according to accessibility, safety, privacy and comfort.

The emotional attachment to places creates the value of the place itself and represents the main drive for environmental protection [94]. Green space generates important benefits for society, such as social cohesion, the promotion of shared interests and the participation of the neighbourhoods [95].

Habitat for species (blue circle) is one of the four main themes identified in our analysis, although it is semantically distant. Habitat services are critical, and they are known as "biodiversity hotspots". Supporting services are crucial for life on Earth. However, unlike the other ecosystem services, the impact on human benefits is indirect or occurs over a very long time, whereas changes in provisioning, regulating and cultural services have relatively direct short-term influences on people. In particular, support services refer to soil formation, whose changes would indirectly affect people through the impact on other services such as the service of food production. Supporting ecosystems also affect the nutrient cycle, i.e., on the availability of mineral elements such as nitrogen, phosphorus and potassium, which are essential for the growth and development of crops and plants, or on the production of biomass and atmospheric oxygen through photosynthesis and habitat provision which has important long-term effects on diversity and species richness. In this regard, forests are the largest provider of ecosystem services, including pollination, seed dispersal, resistance to windstorms, regulation and mitigation of fires, regulation of native insect parasites and invaders, carbon sequestration and cultural ecosystem services in relation to the type, structure and diversity of forests.

\section{Concluding Remarks}

The results of our analysis allowed us to investigate the existing literature on ecosystem services in a fast changing, fragmented and undefined urban territories. The automated content analysis has proved to be an excellent method explore this topic in its entirety and to provide insight on specific aspects of the surveyed Scopus database literature. The "themes" and "concepts" have identified the major foci of the literature and are able to give an all-encompassing understanding of its content that can be used as a guide for further focused reviews [96]. This approach constitutes a starting point for investigating sustainable urban intervention strategies.

The overall perspective on peri-urban ecosystem services can be useful to refocus on the role of environmental studies in order to create more resilient and sustainable cities. The debate regarding ecosystem services frameworks has shifted from their categorizationprovisioning, supporting and regulating, as adopted by the Millennium Ecosystem Assessment to their specific roles played to support local economies, food security and safeguarding health and well-being [17]. However, these services in peri-urban areas are undermined by growing urbanisation, pollution and resource exploitation.

The results show that progressive transitions from compact to dispersed cities has generated more interest in landscape beyond the debate on cities, as nodes of global production networks and classical urban growth studies. With this paper, we proposed a method that, to our knowledge, has not yet been adopted in the field of urban ecosystems. It allows us to explore and synthetize the scientific literature in a context of increasingly digitized information. This methodology is particularly useful to quickly process large amounts of text. Automated content analysis shows its utility compared to manual classification since it limits the subjectivity of human bias.

However, this analysis it is not totally free from subjectivity since it is driven by the researcher, whose interpretation is necessary. To maximize the utility of the approach, other methods should be used in tandem to assist and support expert understanding. 
Supplementary Materials: The following are available online at https: / www.mdpi.com/article/ 10.3390/su13169182/s1, Table S1: The 55 articles published from 2012 to 2021 referring ecosystem services in European peri-urban areas.

Author Contributions: The work is a result of equal contribution and collaboration between the authors in each part of the paper. Conceptualization G.V.; methodology, G.V.; software A.M., G.V. and D.S.; validation, A.M. and T.B.; investigation T.B.; data curation, A.M. and T.B.; writing-original draft preparation, G.V. and D.S.; writing-review and editing, G.V. and D.S.; visualization, T.B.; supervision, G.V. and D.S.; funding acquisition, G.V. All authors have read and agreed to the published version of the manuscript.

Funding: This research was funded by the project "ERRARE-Terre fertili, terre fragili", finanziato nell'ambito di "PIACERI-Piano per la Ricerca di Ateneo 2020-2022", Linea di intervento 2. University of Catania. Project leader: Gabriella Vindigni.

Institutional Review Board Statement: Not applicable.

Informed Consent Statement: Not applicable.

Data Availability Statement: The data presented in this study are available on request from the corresponding author.

Conflicts of Interest: The authors declare no conflict of interest.

\section{References}

1. Mazzeo, G. Impact of high speed trains on the hierarchy of European cities. Jahrb. Reg. 2012, 32, 159-173. [CrossRef]

2. Piano, R. Periferie. 2014. Available online: https://www.renzopianog124.com/pubblicazioni/diario-delle-periferie-2-marghera (accessed on 29 January 2021).

3. Zardini, M. Paesaggi Ibridi. Highway, Multiplicity; Skira: Milan, Italy, 2000.

4. Ellin, N. Integral urbanism; Routledge: London, UK, 2006.

5. Basile, G.; Cavallo, A. Rural identity, authenticity, and sustainability in Italian inner areas. Sustainability 2020, 12, 1272. [CrossRef]

6. Krasilnikova, E.E.; Klimov, D.V. The Main Design Principles of Hybrid Spaces in Terms of the Urban Planning Regeneration. Rudn J. Agron. Anim. Ind. 2016, 4, 63-74. [CrossRef]

7. Jencks, C. The Architecture of the Jumping Universe: A Polemic: How Complexity Science is Changing Architecture and Culture; Academy Editions Ltd.: Newbury, UK, 1997.

8. Pedrazzini, L. Functions and values of peri-urban areas: A multifunctional perspective from eu to lombardy region policies. In Springer Tracts in Civil Engineering; Chen, S., di Prisco, M., Vayas, I., Eds.; Springer: Berlin, Germany, 2017.

9. Zasada, I. Multifunctional peri-urban agriculture-A review of societal demands and the provision of goods and services by farming. Land Use Policy 2011, 28, 639-648. [CrossRef]

10. Balzan, M.V.; Caruana, J.; Zammit, A. Assessing the capacity and flow of ecosystem services in multifunctional landscapes: Evidence of a rural-urban gradient in a Mediterranean small island state. Land Use Policy 2018, 75, 711-725. [CrossRef]

11. La Rosa, D.; Barbarossa, L.; Privitera, R.; Martinico, F. Agriculture and the city: A method for sustainable planning of new forms of agriculture in urban contexts. Land Use Policy 2014, 41, 290-303. [CrossRef]

12. Piorr, A.; Zasada, I.; Doernberg, A.; Zoll, F.; Ramme, W. Research for AGRI Committee-Urban and Peri-Urban Agirculture in the EU. 2018. Available online: https://www.europarl.europa.eu/RegData/etudes/STUD/2018/617468/IPOL_STU(2018)617468_ EN (accessed on 2 February 2021).

13. Spyra, M.; La Rosa, D.; Zasada, I.; Sylla, M.; Shkaruba, A. Governance of ecosystem services trade-offs in peri-urban landscapes. Land Use Policy 2020, 95, 104617. [CrossRef]

14. Fan, P.; Xu, L.; Yue, W.; Chen, J. Accessibility of public urban green space in an urban periphery: The case of Shanghai. Landsc. Urban Plan. 2017, 165, 177-192. [CrossRef]

15. Žlender, V.; Ward Thompson, C. Accessibility and use of peri-urban green space for inner-city dwellers: A comparative study. Landsc. Urban Plan. 2017, 165, 193-205. [CrossRef]

16. La Rosa, D.; Geneletti, D.; Spyra, M.; Albert, C.; Fürst, C. Sustainable planning for peri-urban landscapes. In Ecosystem Services from Forest Landscapes: Broadscale Considerations; Perera, A.H., Peterson, U., Martínez Pastur, G., Iverson, L.R., Eds.; Springer: Berlin, Germany, 2018.

17. Millenium Ecosystem Assessment. Ecosystem and Human Well-Being Synthesis; MEA: Washington, DC, USA, $2005 ;$ Volume 18.

18. Barnaud, C.; Antona, M. Deconstructing ecosystem services: Uncertainties and controversies around a socially constructed concept. Geoforum 2014, 56, 113-123. [CrossRef]

19. Costanza, R.; de Groot, R.; Braat, L.; Kubiszewski, I.; Fioramonti, L.; Sutton, P.; Farber, S.; Grasso, M. Twenty years of ecosystem services: How far have we come and how far do we still need to go? Ecosyst. Serv. 2017, 28, 1-16. [CrossRef] 
20. Czúcz, B.; Arany, I.; Potschin-Young, M.; Bereczki, K.; Kertész, M.; Kiss, M.; Aszalós, R.; Haines-Young, R. Where concepts meet the real world: A systematic review of ecosystem service indicators and their classification using CICES. Ecosyst. Serv. 2018, 29, 145-157. [CrossRef]

21. Abson, D.J.; von Wehrden, H.; Baumgärtner, S.; Fischer, J.; Hanspach, J.; Härdtle, W.; Heinrichs, H.; Klein, A.M.; Lang, D.J.; Martens, P.; et al. Ecosystem services as a boundary object for sustainability. Ecol. Econ. 2014, 103, 29-37. [CrossRef]

22. van den Belt, M.; Stevens, S.M. Transformative agenda, or lost in the translation? A review of top-cited articles in the first four years of Ecosystem Services. Ecosyst. Serv. 2016, 22, 60-72. [CrossRef]

23. Waldheim, C. The Landscape Urbanism Reader; Princeton University Press: Princeton, NJ, USA, 2008.

24. Lee, Y.C.; Ahern, J.; Yeh, C.T. Ecosystem services in peri-urban landscapes: The effects of agricultural landscape change on ecosystem services in Taiwan's western coastal plain. Landsc. Urban Plan. 2015, 139, 137-148. [CrossRef]

25. Stott, I.; Soga, M.; Inger, R.; Gaston, K.J. Land sparing is crucial for urban ecosystem services. Front. Ecol. Environ. 2015, 13, 387-393. [CrossRef]

26. Gillham, O. What Is Sprawl? 2nd ed.; Routledge: London, UK, 2012.

27. Gioffrè, V.; Gioffrè, V. Urban recycle. Regenerative strategies for the "horizontal city" [Riciclare l'urbano. Strategie rigenerative per la "città orizzontale"]. TECHNE 2019, 17, 161.

28. Hedblom, M.; Andersson, E.; Borgström, S. Flexible land-use and undefined governance: From threats to potentials in peri-urban landscape planning. Land Use Policy 2017, 63, 523-527. [CrossRef]

29. Bagaini, A.; Perrone, F.; Nickayin, S. La Valorizzazione del (Non)Consumo di Suolo nei Frammenti di Paesaggio Periurbano. 2017. Available online: https://aisre.it/images/aisre/5971e90ab8edd9.94134479/FullPaper_AISRe_Bagaini_SadatNickayin_Perrone. pdf (accessed on 17 February 2021).

30. Cattivelli, V. Planning peri-urban areas at regional level: The experience of Lombardy and Emilia-Romagna (Italy). Land Use Policy 2021, 103, 105282. [CrossRef]

31. Gallent, N.; Andersson, J.; Bianconi, M. Planning on the Edge; Routledge: London, UK, 2006.

32. Regione Lombardia; DG Sistemi Verdi e Paesaggio. Linee Guida Paesaggistiche per il Governo del Territorio; Regione Lombardia: Milan, Italy, 2011.

33. Galli, M.; Lardon, S.; Marraccini, E.; Bonari, E. Agricultural Management in Peri-Urban Areas: The Experience of an International Workshop; Felici Editore: Pisa, Italy, 2010.

34. Sistema Nazionale per la Protezione dell'Ambiente (SNPA). Consumo di Suolo, Dinamiche Territoriali e Servizi Ecosistemici. 2021. Available online: https:/ /www.snpambiente.it/wp-content/uploads/2021/07/Rapporto_consumo_di_suolo_2021-1.pdf (accessed on 17 February 2021).

35. Burdett, R.; Sudjic, D. Living in the Endless City; Phaidon Press: London, UK, 2011.

36. Adam, M. Definition and Boundaries of the Peri-urban Interface: Patterns in the Patchwork. In Waste Composting for Urban and Peri-Urban Agriculture: Closing the Rural-Urban Nutrient Cycle in Sub-Saharan Africa; Dreschel, P., Kunze, D., Eds.; IWMI: Colombo, Sri Lanka; FAO: Rome, Italy, 2001; pp. 193-208.

37. Gottmann, J. How Large Can Cities Grow? The Johns Hopkins University Press: Baltimore, MD, USA, 1990.

38. Roditi, G. Le citta italiane nell'arena Europea e globale. Competività e attrattività di Milano e della lombardia nelle graduatorie metropolitane. Riv. Geogr. Ital. 2015, 122, 465-474.

39. Raban, J. Soft City; Picador USA: Gordonsville, VA, USA, 1975.

40. Sassen, S. The Global City. New York, London, Tokyo; Princeton University: Princeton, NJ, USA, 1991.

41. Sorkin, M. Variations on a Theme Park: The New American City and the End of Public Space; Macmillan: New York, NY, USA, 1992.

42. Pisano, C.; Saddi, V. Open and closed figures in dutch spatial planning. In Shaping Regional Futures: Designing and Visioning in Governance Rescaling; Lingua, V., Balz, V., Eds.; Springer: Berlin, Germany, 2019.

43. Ungers, O.M. The City in the City: Berlin as a Green Archipelago; Lars Muller Publishers: Zurich, Switzerland, 2013.

44. Corboz André La Suisse, Comme Hyperville. 1998. Available online: https:/ /it.scribd.com/document/182349621/CORBOZ-LaSuisse-Comme-Hyperville (accessed on 17 February 2021).

45. Robinson, D.A.; Panagos, P.; Borrelli, P.; Jones, A.; Montanarella, L.; Tye, A.; Obst, C.G. Soil natural capital in Europe; A framework for state and change assessment. Sci. Rep. 2017, 7, 6706. [CrossRef]

46. Alexa, M.; Zuell, C. Text analysis software: Commonalities, differences and limitations: The results of a review. Qual. Quant. 2000, 34, 299-321. [CrossRef]

47. Berger, A. Drosscape: Wasting Land in Urban America; Princeton Architectural Press: Princeton, NJ, USA, 2006.

48. Clément, G. Manifeste du Tiers Paysage; Sens\&Tonka: Paris, France, 2014.

49. Déjeant-Pons, M. The European landscape convention. Proc. Landsc. Res. 2006, 31. [CrossRef]

50. Luederitz, C.; Brink, E.; Gralla, F.; Hermelingmeier, V.; Meyer, M.; Niven, L.; Panzer, L.; Partelow, S.; Rau, A.L.; Sasaki, R.; et al. A review of urban ecosystem services: Six key challenges for future research. Ecosyst. Serv. 2015, 14, 98-112. [CrossRef]

51. R Core Team. R Development Core Team. R A Lang. Environ. Stat. Comput. 2016, 55, 275-286.

52. Wickham, H. ggplot2: Elegant Graphics for Data Analysis; Springer: New York, NY, USA, 2009; Volume 35.

53. Blei, D.M. Probabilistic topic models. Commun. ACM 2012, 55, 77-84. [CrossRef]

54. Smith, A.E.; Humphreys, M.S. Evaluation of unsupervised semantic mapping of natural language with Leximancer concept mapping. Behav. Res. Methods 2006, 38, 262-279. [CrossRef] 
55. Krippendorff, K. Commentary: A Dissenting View on So-Called Paradoxes of Reliability Coefficients. Ann. Int. Commun. Assoc. 2013, 36, 481-499. [CrossRef]

56. Haynes, E.; Garside, R.; Green, J.; Kelly, M.P.; Thomas, J.; Guell, C. Semiautomated text analytics for qualitative data synthesis. Res. Synth. Methods 2019, 10, 452-464. [CrossRef] [PubMed]

57. Roberts, C.W. A Conceptual Framework for Quantitative Text Analysis. Qual. Quant. 2000, 34, 259-274. [CrossRef]

58. Crofts, K.; Bisman, J. Interrogating accountability. Qual. Res. Account. Manag. 2010, 7, 180-207. [CrossRef]

59. Gapp, R. Discovering the Value in Using Leximancer for Complex Qualitative Data Analysis. 2014. Available online: https: / / www.academia.edu/4356731/Discovering_the_value_in_using_Leximancer_for_complex_qualitative_data_analysis (accessed on 26 January 2021).

60. Costanza, R.; D’Arge, R.; De Groot, R.; Farber, S.; Grasso, M.; Hannon, B.; Limburg, K.; Naeem, S.; O’Neill, R.V.; Paruelo, J.; et al. The value of the world's ecosystem services and natural capital. Nature 1997, 387, 253-260. [CrossRef]

61. Martín-López, B.; Iniesta-Arandia, I.; García-Llorente, M.; Palomo, I.; Casado-Arzuaga, I.; Del Amo, D.G.; Gómez-Baggethun, E.; Oteros-Rozas, E.; Palacios-Agundez, I.; Willaarts, B.; et al. Uncovering ecosystem service bundles through social preferences. PLoS ONE 2012, 7, e38970. [CrossRef] [PubMed]

62. Kumar, P. The economics of Ecosystems and Biodiversity: Ecological and Economic Foundations; Routledge: London, UK, 2012.

63. Haase, D.; Schwarz, N.; Strohbach, M.; Kroll, F.; Seppelt, R. Synergies, trade-offs, and losses of ecosystem services in urban regions: An integrated multiscale framework applied to the leipzig-halle region, Germany. Ecol. Soc. 2012, 17. [CrossRef]

64. de Groot, R.S.; Alkemade, R.; Braat, L.; Hein, L.; Willemen, L. Challenges in integrating the concept of ecosystem services and values in landscape planning, management and decision making. Ecol. Complex. 2010, 7, 260-272. [CrossRef]

65. Elmqvist, T.; Goodness, J.; Marcotullio, P.J.; Parnell, S.; Sendstad, M.; Wilkinson, C.; Fragkias, M.; Güneralp, B.; McDonald, R.I.; Schewenius, M.; et al. Urbanization, Biodiversity and Ecosystem Services: Challenges and Opportunities: A Global Assessment; Springer: Berlin, Germany, 2013.

66. Kirchner, M.; Schmidt, J.; Kindermann, G.; Kulmer, V.; Mitter, H.; Prettenthaler, F.; Rüdisser, J.; Schauppenlehner, T.; Schönhart, M.; Strauss, F.; et al. Ecosystem services and economic development in Austrian agricultural landscapes-The impact of policy and climate change scenarios on trade-offs and synergies. Ecol. Econ. 2015, 109, 161-174. [CrossRef]

67. Primmer, E.; Jokinen, P.; Blicharska, M.; Barton, D.N.; Bugter, R.; Potschin, M. Governance of Ecosystem Services: A framework for empirical analysis. Ecosyst. Serv. 2015, 16, 158-166. [CrossRef]

68. Hampwaye, G. Benefits of urban agriculture: Reality or illusion? Geoforum 2013, 49, R7-R8. [CrossRef]

69. Ecosystems and Human Well-Being: Wetlands and Water. 2016. Available online: https:/ /www.millenniumassessment.org/ documents / document.358.aspx.pdf (accessed on 2 February 2021).

70. Swinton, S.M.; Lupi, F.; Robertson, G.P.; Hamilton, S.K. Ecosystem services and agriculture: Cultivating agricultural ecosystems for diverse benefits. Ecol. Econ. 2007, 64, 245-252. [CrossRef]

71. Duží, B.; Frantál, B.; Simon Rojo, M. The geography of urban agriculture: New trends and challenges. Morav. Geogr. Rep. 2017, 25, 130-138. [CrossRef]

72. Pinto-Correia, T.; Almeida, M.; Gonzalez, C. Transition from production to lifestyle farming: New management arrangements in Portuguese small farms. Int. J. Biodivers. Sci. Ecosyst. Serv. Manag. 2017, 13, 136-146. [CrossRef]

73. Artmann, M.; Sartison, K. The role of urban agriculture as a nature-based solution: A review for developing a systemic assessment framework. Sustainability 2018, 10, 1937. [CrossRef]

74. McGranahan, G.; Balk, D.; Anderson, B. The rising tide: Assessing the risks of climate change and human settlements in low elevation coastal zones. Environ. Urban. 2007, 19, 17-37. [CrossRef]

75. European Commission. The Implementation of the Soil Thematic Strategy and Ongoing Activities; Office of the European Union: Luxemburg, 2012.

76. FAO. The State of Food Insecurity in the World; FAO, IFAD, UNICEF, WFP and WHO: New York, NY, USA, 2019.

77. Calzolari, C.; Tarocco, P.; Lombardo, N.; Marchi, N.; Ungaro, F. Assessing soil ecosystem services in urban and peri-urban areas: From urban soils survey to providing support tool for urban planning. Land Use Policy 2020, 99, 105037. [CrossRef]

78. Dewaelheyns, V.; Rogge, E.; Gulinck, H. Putting domestic gardens on the agenda using empirical spatial data: The case of Flanders. Appl. Geogr. 2014, 50, 132-143. [CrossRef]

79. Paquette, S.; Domon, G. Changing ruralities, changing landscapes: Exploring social recomposition using a multi-scale approach. J. Rural Stud. 2003, 19, 425-444. [CrossRef]

80. Phillips, M.; Page, S.; Saratsi, E.; Tansey, K.; Moore, K. Diversity, scale and green landscapes in the gentrification process: Traversing ecological and social science perspectives. Appl. Geogr. 2008, 28, 425-444. [CrossRef]

81. Daniel, T.C.; Muhar, A.; Arnberger, A.; Aznar, O.; Boyd, J.W.; Chan, K.M.A.; Costanza, R.; Elmqvist, T.; Flint, C.G.; Gobster, P.H.; et al. Contributions of cultural services to the ecosystem services agenda. Proc. Natl. Acad. Sci. USA 2012, 109, 8812-8819. [CrossRef]

82. Dramstad, W.E.; Tveit, M.S.; Fjellstad, W.J.; Fry, G.L.A. Relationships between visual landscape preferences and map-based indicators of landscape structure. Landsc. Urban Plan. 2006, 78, 465-474. [CrossRef]

83. Fürst, C.; Frank, S.; Witt, A.; Koschke, L.; Makeschin, F. Assessment of the effects of forest land use strategies on the provision of ecosystem services at regional scale. J. Environ. Manag. 2013, 127, S96-S116. [CrossRef] 
84. Marull, J.; Pino, J.; Tello, E.; Cordobilla, M.J. Social metabolism, landscape change and land-use planning in the Barcelona Metropolitan Region. Land Use Policy 2010, 27, 497-510. [CrossRef]

85. Tengberg, A.; Fredholm, S.; Eliasson, I.; Knez, I.; Saltzman, K.; Wetterberg, O. Cultural ecosystem services provided by landscapes: Assessment of heritage values and identity. Ecosyst. Serv. 2012, 2, 14-26. [CrossRef]

86. Andersson, E.; Barthel, S.; Borgström, S.; Colding, J.; Elmqvist, T.; Folke, C.; Gren, Å. Reconnecting cities to the biosphere: Stewardship of green infrastructure and urban ecosystem services. AMBIO 2014, 43, 445-453. [CrossRef]

87. Chan, K.M.A.; Guerry, A.D.; Balvanera, P.; Klain, S.; Satterfield, T.; Basurto, X.; Bostrom, A.; Chuenpagdee, R.; Gould, R.; Halpern, B.S.; et al. Where are cultural and social in ecosystem services? A framework for constructive engagement. Bioscience 2012, 62, 744-756. [CrossRef]

88. Van den Berg, A.E.; Koole, S.L. New wilderness in the Netherlands: An investigation of visual preferences for nature development landscapes. Landsc. Urban Plan. 2006, 78, 362-372. [CrossRef]

89. Komossa, F.; van der Zanden, E.H.; Verburg, P.H. Characterizing outdoor recreation user groups: A typology of peri-urban recreationists in the Kromme Rijn area, the Netherlands. Land Use Policy 2019, 80, 246-258. [CrossRef]

90. Holdnak, A.; Holand, S.M. EDU tourism: Vacationing to learn. J. Park. Recreat. 1996, 31, 72-75.

91. Smith, C. Tax Reform and State Education Spending: Lessons Learned in Michigan. Policy Perspect. 1997, 4, 60. [CrossRef]

92. Sharpley, R.; Jepson, D. Rural tourism A spiritual experience? Ann. Tour. Res. 2011, 38, 52-71. [CrossRef]

93. Kline, J.D. Tourism and natural resource management: A general overview of research and issues. Gen. Tech. Rep. 2001. [CrossRef]

94. Feldman, R.M. Settlement-identity: Psychological Bonds with Home Places in a Mobile Society. Environ. Behav. 1990, 22, 183-229. [CrossRef]

95. Gotham, K.F.; Brumley, K. Using Space: Agency and Identity in a Public-Housing Development. City Community 2002, 1, 267-289. [CrossRef]

96. Nunez-Mir, G.C.; Iannone, B.V.; Pijanowski, B.C.; Kong, N.; Fei, S. Automated content analysis: Addressing the big literature challenge in ecology and evolution. Methods Ecol. Evol. 2016, 7, 1262-1272. [CrossRef] 